\title{
Understanding the Pull Motivations of Malaysian Women Music Teachers as Music Entrepreneurs
}

\author{
Cheong Ku Wing \\ Cultural Centre, University of Malaya \\ Wilayah Persekutuan Kuala Lumpur, Malaysia \\ e-mail: kwcheong@um.edu.my
}

Published online: 5 September 2018

Cite this article: Cheong, K.W. (2018). Understanding the pull motivations of Malaysian women music teachers as music entrepreneurs. Malaysian Journal of Music, 7, 78-99.

\begin{abstract}
Entrepreneurship generally refers to small business ownership which implies quality of innovation and initiative in creating a new venture. Previous studies on entrepreneurship have indicated that pull and push factors in motivation and the environmental influences are the two main dynamic aspects that prompt women into their decision in creating their own business. In the Malaysian context, some women music teachers have ventured into establishing music businesses after several years of contribution in music teaching. What are the pull factors and influences that prompted these women music teachers into music business ownership after some years of music teaching? This study aims to examine and explore the pull motivational and influencing factors of why women music teachers endeavour in setting up music studios, music schools and entering into small music business ownership. In-depth interviews were conducted with 3 women music entrepreneurs and data was analysed for emerging themes. The findings provided evidence for the better understanding of the pull motivational and influencing factors of the women music entrepreneurs.
\end{abstract}

Keywords: Malaysian women music teachers, music entrepreneurs, pull motivations

\section{Introduction}

Entrepreneurship refers to small business ownership which implies quality of innovation, initiative and creativity in establishing a new venture. Drucker (1985) defined entrepreneurship as an innovation that endows the existing resources with new capabilities for the creation of business. It is a process of starting a business with the ability and readiness in developing, organising and managing a business 
venture for the reward of making profit characterised by innovation, risk-taking and growth (Mirchandani, 2005, p. 253).

The characteristics of an entrepreneur are described as an individual who aims to create new products with different values (Drucker, 1985, p. 22); in search of change; respond to the changes; and further exploit the changes as an opportunity (p. 28). He further identified creativity and innovation as the significant qualities in entrepreneurship in which entrepreneurs draw the inspiration and integrate into innovation. Motivation is a forward drive that propels one towards the direction in realising self-goal. Entrepreneurial motivation that maintains the entrepreneurial spirit plays an important role in shaping the entrepreneurs' direction, intensity, and persistence. Shane, Locke and Collins (2003) proposed that human motivation has vital influence on entrepreneurial decision (p. 257) and significant contribution to the entrepreneurial creative engagement in 'rearrange' or 'recombine' resources in new and noble ways (p. 259). From previous studies on entrepreneurial motivation, influencing factors are summarised as achievement needs, risk taking, tolerance for ambiguity, locus of control, self-efficacy and goal setting, independence, drive and passion (Aftan \& Hanap, 2018; Barba-Sanchez \& Atienza-Sahuquillo, 2017; Shane, Locke, \& Collins, 2003).

The women's entrepreneurial motivations to start up for business are varied. In earlier study, Orhan (2005) surveyed on the women's motivational factors into the ownership of small business and the findings indicated that personal background in terms of education and professional experience; family influence and other push and pull factors contribute to the entrepreneurial decision. He discussed that push factors are characterised by behaviour manifested with external rewards and challenging conditions which are out of necessities such as dissatisfaction, frustration and boredom with previous job; striving for a job; wishing for a flexible schedule to balance between work and family; and supplementing the limited means of family income. However, entrepreneurial pull motivations are characterised by personal aspiration in entrepreneurial challenges to unleash entrepreneurial potential and to prospect the 'future value for the individuals' (p. 4). Orhan (2005) further elaborated that independence and self-fulfilment are the prime pull factors which motivate women to start a business. Other motivation includes flexibility, social contribution and affiliation (p. 4). Besides push and pull motivations, environmental factors are the drive that leads women into entrepreneurship

Previous and recent studies have suggested few push/pull factors that influence women's decision into entrepreneurship, which includes independence and self-achievement, time flexibility to manage the time balance juggling between work and family (Chamorro-Premuzic, Rinaldi, Akhtara, \& Ahmetoglul, 2014; MasTur, Soriano, \& Roig-Tierno, 2015; Orhan, 2005). Pandey (2013) also suggested personal satisfaction, self-actualisation and self-confidence as the interacting motivational factors among the women entrepreneurs. Nassif, Andreassi, Tonelli, and Fleury (2012) identified women's entrepreneurial competencies that relate to entrepreneurial motivation included perceptions of potentialities and opportunities; desires, leadership; interpersonal skills; social concerns and commitment.

Music teachers as a profession have combined identities as musicians and 
educators, which draw on different fields of knowledge and expertise. Elliott (1995) identified the qualities of an excellent music teacher as one who are musically, pedagogically, philosophically, psychologically savvy (p. 309). Professionally, the impression of private music teachers' has always been characterised as entrepreneurial (Smith, 2014, p. 70). Smith described the entrepreneurial qualities of music teachers as 'good musicians'; 'responsible' and 'collaborative' and competent in 'administrative details'; good in communication skills, clearly and confidently; 'recruitment'; and 'agents of social change' (pp. 70-72).

The nature of the music teacher's profession is generally described as freelance, flexible, and in a way, self-employed teaching from home studio or commute to students' home, or part-time basis engage their music teaching at the music schools or music centres. Successful music teachers often exhibit their entrepreneurial qualities and career choices in search of autonomy and independence. In recent years, Malaysia has seen a considerable increase in music teachers setting up own music school and music business. These music teachers have shown to be enterprising in the pursuit of realising their creative potential, moving their career forward and venturing into music business ownership after some years of contribution in music teaching. The growing number of music entrepreneur may be associated with music teachers who seek new challenges to find new meaning in their career through entrepreneurial accomplishments. Though, what are the attractive factors that draw the music teachers to set up a music business, so called 'baby' which demands much of their attention, time investment and care? What are the entrepreneurial motivations that prompt them into a music business and to have an ownership of a music school?

Previous studies have discussed on entrepreneurship and women entrepreneurs (Chamorro-Premuzic, Rinaldi, Akhtara, \& Ahmetoglu, 2014; MasTur, Soriano, \& Roig-Tierno, 2015; Suárez-Ortega \& Gálvez-García, 2017; Tlaiss, 2015). However, there is a paucity of research and scarce literature which investigate the area of music teachers as music entrepreneurs. Therefore, it is necessary to conduct studies to understand the entrepreneurial motivations and the influencing factors that draw female music teachers into music business.

\section{Methodology}

The in-depth phenomenological interview method was employed to generate insights of three women music entrepreneurs about their entrepreneurial motivations and influencing factors on embarking a music business. In-depth interview is the most common qualitative method in used in social research (Denzin, 1989; Morris, 2015). As stated by Morris (2015), interview is a 'powerful way to collect data' (p. 1), it enables the interviewees to share their thoughts and reflections; recall memories and experiences; express motives and interpretations; articulate understandings and perceptions (p. 5) of the concerned issues. 


\section{Participants}

This case study used a small number of participants to examine the interview discourse in depth. A case study is a detailed and comprehensive analysis of one or few individuals (Fraenkel, Wallen, \& Hyun, 2012, p. 21). The participants were 3 music teachers who have been contributing their music and music education knowledge, experience and expertise to the music industry, while simultaneously managing own music school. The case selection was based on purposive sampling and the selection criteria depended on the success of the participants' music entrepreneurship, years and duration in the music industry. The selection of participants was through referrals and recommendation based on the stipulated criteria, which includes extensive experience, evidence of status and reputation as a music teacher and music entrepreneur. The music entrepreneurs in this study commenced their teaching career in their early 20's. After several years of teaching as private music teachers and teaching at a music school, gaining sufficient knowledge and experience for entrepreneurial application, decision was made to establish their music business in their mid-20s. In Van der Boon (2005), the majority of the women who considered venture into their own business were aged 35.

The introductory contact with the music entrepreneurs was made through WhatsApp Messenger followed by e-mails to clarify the aim of the study. They were advised that their responses gathered from the interview would remain anonymous. For the discussion in this study, the identity of each participant was coded as Music Entrepreneur 1 (ME1), Music Entrepreneur 2 (ME2), and Music Entrepreneur 3 (ME3) according to the sequence of the date interviewed.

\section{Data Collection and Data Analysis Procedures}

The interviews were conducted at their music business premises, a location which is familiar and comfortable (Oltmann, 2016) for the interviewees to allow 'flexible and free-flowing interaction' (Morris, 2015, p. 3). English was used as a medium of communication as it is the first language of all participants and the interviewer. The flow of the interviews involved the questions and responses between interviewinterviewee to capture the depth and richness of the participants' entrepreneurial experience for a detailed study and analysis. The length of interview for each participant was for about an hour.

The interview process was modelled on Seidman's (2013) three-interview series which involves 3 phases: (1) focused life history; (2) details of experience; and (3) reflection on the meaning (pp. 20-23). Face-to-face semi-structured in-depth interview process was conducted commencing with general questions concerning their personal demographics (age, marital status, educational background and music teaching experiences). This was followed by some general questions to gain information on the music business (years of entrepreneurial experience, setup of the music business). This was then sequenced by semi-structured questions to explore the participants' entrepreneurial motivation, goals and aspiration focussed on the 
motivational factors, entrepreneurial decision-making process, entrepreneurial process, influencing factors and personal characteristics. The interviews conclude with participants' reflection on the meaning and significance of music entrepreneurship in their work and life.

The interviews were audio-recorded with prior obtained permission from the participants. The qualitative interview data is the primary source of data collection. Interviews data were transcribed verbatim, read and checked for accuracy with repeated listening to the recording. The transcription was analysed employed naturalistic coding to generate insights on the participants' entrepreneurial motivation and the influencing factors. To ensure the trustworthiness of the collected data, the final full transcripts were e mailed to the participants for their acknowledgment of accuracy. This is followed up by telephone calls to clarify some ambiguous issues.

Meaningful patterns from the interview data were identified through the thematic analysis. The data analysis procedure follows the 6-phase process of thematic analysis suggested by Braun and Clarke (2006) that is, familiarisation with the data, preliminary coding, developing themes, and revising themes, defining and establishing themes, extracting meaningful data, presenting the analytic narrative discourse. The transcribed interview manuscript was read, re-read and critically examined. Meaningful patterns were identified through the process of familiarisation, immersion and coding of the data. The preliminary codes were generated with constant comparison with the purpose of study and also with the findings of the previous studies to seek and identify new themes. Inter-coder reliability test was conducted to calculate similarity percentage using Kappa analysis from SPSS. The Cohen's Kappa was used to quantify the degree of agreement between the coders. The Kappa value between Coder 1, 2 and 3 ranged from .71 to .86 , which is considered as reliable.

\section{Thematic Discussion}

Music teachers have their individual core values and motivations that drive them to choose entrepreneurship. In this study, the findings indicate the similarities and differences among the music entrepreneurs in their motivational needs in entering music business to realise their potential in music entrepreneurship. Thematic analysis of the interview data identified the entrepreneurial motivations which included personal pull motives like self-fulfilment, passion, meaningful experiences, challenges, opportunities seeking and professional collegial affiliation; and environmental factors include family and home environment; mentor and role model; and meaningful experience. These emerging themes are discussed accordingly below.

\section{Self-fulfilment}

According to Gewirth (1998), self-fulfilment is an ideal to actualise one's deepest 
passion and capacities; for the inner best to develop and emerge through aspiration and potentialities (p. 3) which embody excellence and achievement. ME 1 said that after gaining relevant teaching experience and some meaningful exposures, she was aspired to challenge herself to explore a more meaningful and purposeful professional life as a music educators. Her original intention was personal, to start off a music school with ideal music curriculum for her children to receive highquality music education. She further emphasised her vision is to prioritise the quality in the provision of music education and to share the gift of music. It was her aspiration to design a holistic music curriculum to stimulate enthusiasm; to cultivate interest and to develop music knowledge and creativity among young musicians. For ME 1,

My ultimate goal is to provide meaningful musical experiences to the music students. It is worthwhile to devote my efforts and resources to attain this vison. It is the sense of satisfaction and gratification through many efforts that keeps me focussed, grounded and sustained.

Similarly, ME 2 also shared the same concern indicating that high standards in music education is her lifelong devotion and challenges to promote musical and meaningful learning experiences to enhance and support students' musical achievement. She stated that her notion of music education is to emphasise the musical quality, for every students to develop artistic musicianship and musical abilities. She explained that music it is important for music students to love, appreciate, and enjoy music. She advocated that music learning is not about examination, but to engage students in active music making for the aesthetic purposes. She strongly believed that every child has the potential to achieve a high level of artistic performance to their musical expression in emotion and for their own enjoyment. She indicated that,

Everyone has an innate ability to learn. It is my educational ambition and responsibility to nurture positive musical behaviour among young musicians.

As with the others, ME 3 also expressed the same commitment in placing values and quality of music education in the lives of the students. She recognised the entrepreneurial journey as a process of sustaining efforts and achievement which foster fulfilment with much perseverance and patience. However, she also remarked that it is enjoyable and gratifying:

It is the challenge and responsibility of music educators to assure high-standards of quality in the music teaching-learning process, to educate and to inspire young musicians to achieve their musical goals and to realise their creative potential to the fullest.

When asked on their views on self-fulfilment as a music entrepreneurship owner as compared to the entrepreneurial characteristics of a private music teacher, ME 1 and ME 2 paused and reflected; and commented that the needs of self-fulfilment as 
a music educators are similar for both identities. They unanimously agreed that the ownership of a music school business with a larger setting provides space, resources and manpower to organise and support music projects like master classes, choir, orchestra, ensembles and music festivals. Also, in a wider societal context with a larger scale of collaborative resources enable them to explore new and innovative ways to address issues in music teaching and learning and share the ideas to the community.

ME 2 further emphasised that the entrepreneurial context enables the exploration, discussion and presentation of her music education ideology to the community in a sustainable and innovative ways, which is largely shared by entrepreneurial music activities and projects. She said,

I enjoy organising music concerts and activities....it is worthwhile and rewarding to be part of talent nurturing, providing environment for the young musicians to develop their performance skills; to inspire musical excellence...... and most importantly positive attitudes to embrace musical values.

ME 1 also vision her entrepreneurial setting as a platform to provide support to the young and individual musicians for the development of music talents and potential; a place to provide assistance and opportunity to the young budding musicians in their career development. ME 3 reflected insightfully stating that it is meaningful to share an important part of our musicians' lives with others, helping and shaping them to achieve their aesthetic ideals.

The music entrepreneurs also shared that the self-fulfilment is not of the desire of material goals. The monetary reward from the music business is secondary incentive and less important as compared to what stated by ME 2, is to bring about a community which concerned about aesthetic excellence and artistic standards.

Previous studies also indicated that women were pulled and motivated towards entrepreneurship to achieve self-fulfilment (Tlaiss, 2015), gratification and satisfaction (Przepiorka, 2016). Kokun (2015) indicated that professional selfrealisation maps 'clear and meaningful ways of professional self-fulfilment' (p. 19); and professional self-fulfilment shapes 'life self-fulfilment' through manifesting own potential and abilities (p. 20).

In this study, all three music entrepreneurs concurred that self-fulfilment is the key motivation of their efforts in music entrepreneurship which has great impact on their music profession and continuously unfolds their full potentials as musician and music educator. They were pulled towards entrepreneurship for their personal desires of fulfilling aspiration to achieve quality in music education and to help young musicians to realise their musical potentials. To these music entrepreneurs, their contributions to the young musicians in musical achievement are meaningful and purposeful as music educators and their vision can be realised through efforts and resources of their entrepreneurship. The self-fulfilment is realised through selfactualisation; characterised by professional aspiration; and self-realisation of their professional vison, efforts and resources.

As noted by Maslow's (1987) hierarchy of needs theory, self-actualisation is the self-growth towards self-fulfilment of the highest needs culminated in the 
gratification of meaning and values in life. The women music entrepreneurs actualise their self-fulfilment through their entrepreneurial journey, potentials, experience, purposes and attainment to realise their life values and goals.

\section{Passion}

Entrepreneurial passion has gradually gained much interest by researchers (Bhansing, 2017; Cardon, Zietsmab, Saparitoc, Matherned, \& Davise, 2005; Cardon, Wincent, Singh, \& Drnovsek, 2009). Laaksonen, Ainamo and Karjalainen (2011) explored the entrepreneurial passion among heavy metal musicians and conceptualised passion as the motivational drive for entrepreneurship which evidenced in their genuine love for work with pride and commitment. It is also the entrepreneurial desire that facilitates innovation with 'empowerment, energy and a drive for perfection' and enables 'opportunity recognition and execution' (p. 31).

The music entrepreneurs in this study recognise their self-identity as musicians, educators and entrepreneurs. It is through these professional identities that their passion and love for music and education are manifested through. They metaphorically relate the entrepreneurial product as their 'baby' in which effort and energy have invested with sustaining commitment. As appraised by ME3, it is a devotion to 'nurture with love and passion' and to maintain strong emotions and enthusiasm in sustaining the entrepreneurial activities.

The passion in music teachers is significant in fuelling their entrepreneurial motivation in taking challenges in their professional lives. According to the participants, these challenges give them meaning and purpose in life in fulfilling their own mission to achieve self-value in providing best music education to the community and society. All participants expressed that their passion for music and education is vital in sustaining their entrepreneurial endeavour; an 'essential attribute underpinning and driving entrepreneurship' (Dalborg \& Wincent, 2015, p. 975). ME 1 shared her ideals,

Music education is my passion ... to nurture and inspire young musicians ... it is important to enhance their music journey with good and committed teaching.

She emphasised the importance of passion,

Passion leads to excellence and stimulated creativity.

According to her, the passion for music profession is the constant motivation to continually appropriating and adapting teaching ideas and strategies to create a challenging, enriching music learning environment for the students. Creating and generating strategies and challenges are effective in building and strengthening entrepreneurial skills. As stated by Bhansing, Hitters and Wijngaarden (2017), passion is the crux of entrepreneurship which nurtures creativity and enables entrepreneurs to recognise new opportunities and gives meaning to the 
entrepreneurial accomplishments.

These music entrepreneurs shared their entrepreneurial journeys and revealed that they are musicians and music educators at heart with limited previous knowledge and experiences of founding a business. However, they reflected that passion plays a central role as the personal drive to entrepreneurial achievement and creativity. ME 1 commented that,

I do not have any knowledge nor experience in business, it is not the monetary that I am looking for ... it is always the creative musical achievement and excellence in music education that matters" (ME1)

ME 2 added that,

It is not just the entrepreneurial passion; it is also the passion for music and teaching that ignite this music business.

They concurred that music belongs to every child and everyone. It is their passion to share this gift, through their professionalism and their entrepreneurial activities to reach out and initiate contact to the community to have the 'spark of joy' through music.

In sum, passion plays an important role in driven us to success and achievement, it is a powerful drive to 'create, invent, and improve' (Spinelli \& Adams, 2012, p. 40). It is regarded as the vital characteristics of successful entrepreneurs (Cardon et al., 2009). Entrepreneurial motivation cantered round the entrepreneurial passion. This passion is not just the 'business'; itself but also the music teachers' professional passion.

\section{Challenges and Risk-taking}

Entrepreneurs are prepared for challenges and risks in the entrepreneurial process. All three music entrepreneurs indicated that facing challenges and risk-taking are inevitable in entrepreneurship; element of risk is an important entrepreneurial skill to develop strategic thinking and planning.

ME 2 shared her experiences as a young entrepreneur organising music activities and music festivals in her entrepreneurial path. She recalled that:

I was young and lesser in experience; however, it was my nature of risk taking that propels my career forward ... I am also very responsive the changes and risk.

Risk-taking provided her great opportunities for meaningful learning; learning from mistakes; experience success and failure in pursuing the entrepreneurial activities and ventures. ME 1 said that she has gained much knowledge and experience through her entrepreneurship process, not just as a music teacher but also a manager and business owner in which she enjoyed these diverse 
identities.

All 3 music entrepreneurs indicated that entering into entrepreneurship was an opportunity for knowledge acquisition, personal challenge and growth. They emphasised their entrepreneurial goals are not by the pursuit of profit-making. However, they also indicated their concerns on managing the operational expenditure and the responsibility and effort to maintain and grow their music business.

ME 2 commented that it is important to share professional knowledge, experience and enjoyment with others. For her, the music venture is a platform for sharing and working with other music teachers. She passionately commented that:

It is a way to help and support each other in achieving the common vison for the excellence in music education.

They exclaimed that sharing musical and teaching knowledge is an important challenge; which gives meaning and purpose in self and professional development; and agreed that the challenges they face in music entrepreneurship was not pivot on monetary rewards but to share their expertise, beliefs, values; the philosophy and principles of music education with other fellow colleagues. ME 2 noted that the reward is humanistic that gives meaning, purpose and profound value, not just to her music profession but her life. ME 3 shared collective view the others indicating that her music entrepreneurial intention was to achieve her personal life themes and life values and as well as contributing to the others, students, novice music teachers and colleagues.

These music entrepreneurs have well established themselves in the music industry and received good reputation as music educator. They reflected that these lifelong challenges have given meaning and purpose to their personal and professional lives. Their values and goals as an excellent music teacher are established on reflective learning to bring about appropriate musical and educational challenges for self-growth and self-knowledge. It is their desire, challenge and responsibility to be acknowledged as an excellent and influential role model for novice music educators and also to share their vision, passion and enthusiasm to others in realising the values of music and music education. They do not pivot their challenges and achievement on material or monetary rewards but have deep convictions sharing the value of music and music education with others.

Wallevik (2015) indicated that the challenge in $21^{\text {st }}$ century entrepreneurship is the strategy of combining roles and resources to gain growth in music business (p. 15). Arora (2015) emphasised the importance of entrepreneurs to be adaptive to changes for sustainable innovation. In this study, the women music entrepreneurs pursue their life values and goals; take up challenges and risks; and unleash their entrepreneurial potential through professional self-knowledge and selfgrowth. 


\section{Opportunities Seeking}

The successful entrepreneurs are characterised by their ways of creating opportunities. They are always in pursuit of imagined opportunities, setting and attaining goals. In the music industry, entrepreneurship is vital in musicians' professional lives (Barker, 2017). It involves abilities in seeking, recognising and advantaging emerging opportunities and creative skills for sustainability.

Music entrepreneurship, setting up music business and music school is a locality based entrepreneurship to serve the community. Among the entrepreneurial opportunities, identification of a strategic business location is considered a vital component. For the music entrepreneurs in this study, the ownership of a music business is to seek a career forward advancement from their job as piano/music teacher teaching from home. They agreed that business locality signifies business opportunities and it is utmost important to search and recognise an ideal location to establish their music business. Further, they indicated that other than establishing a business, they also desire to continue the have the balance between career and family. Therefore, the selection of a strategic locality is utmost important for them to commute between home and business location. Moreover, music business location is ultimate important to place and space that is convenient and comfortable for the customers (music students and their parents).

Other than opportunities seeking for business locality and its potential, seeking and creating opportunities for promising ideas; strategy to implement the ideas; checking on the efficiency of the planning; and realising the aspiration is a process involving continuous efforts. ME 2 positively stated that as entrepreneurs, she has dreams to achieve; an aspiration to actualise.

ME 1 and 2 both stated that their musical and pedagogic knowledge are the sources for creating opportunities. From their prior professional knowledge and experience, they recognise the importance of Arts education as a whole. They set forth to the entrepreneurship with a vision of integrating music with other arts like dance, drama and visual arts (painting and drawing). ME 2 said:

Music and dance are closely related and have common characteristics in enhancing each other.

She elaborated that opportunities seeking is to combine and recombine resources,

The combination of two arts disciplines will deepen and broaden music or art learning.

From the pedagogic perspectives, she suggested that it is vital for pianists to play dance music and to accompany the dances. It is an enjoyable way of learning in developing musical skills, and to foster a better understanding of the dances and hence improve their music interpretation. She said: 
The pianists will increase their repertoire through accompanying the dancers; they will also develop and improve their other musicianship skills like sight reading. At the same time, they learn about dances and the interpretation of these dances.

ME 1 also strongly emphasised that her dream and vision is to have music and dance school. From her earlier experience, she realised the importance of musicians to understand dance music, as these two arts are closely related. She indicates that there are holistic ways of learning music and values eclectic approaches to music learning.

Both ME 1 and 2 are not impulsive in achieving their goals. Other than having clear goals, they also have strategic plan well mapped. ME 2 indicated that she may be spontaneous in her creative ideation, but definitely she is not impetuous in her decision-making and plan execution. She said:

I am realistic with my plan....I need time to develop the students performing ability before they are able to accompany the dances musically and professionally.

ME 3 also shared that she had a long-term plan for her choir to attain international level. She reflected that there were much dissatisfaction and rejections in the earlier years and there were times of contemplation to persevere and move forward or let go the dream and move out. She said, however,

I am emotionally determined and persistent to embrace disappointment and failures and keep moving forward. There were much efforts and energy devoted to reflect, evaluate, synthesise ideas, implement strategic plan.

She expressed gladly that in the recent years, the continual efforts joint with the other colleagues, and the community of students and parents have yield fruitful and desirable outcomes through clear plan and professional commitment.

In this study, the music entrepreneurs combine their passion for creativity; problem finding and solving skills with business strategies and innovation. As stated by Short, Ketchen, Shook and Ireland (2010), ideas and dreams have possibilities to evolve into opportunities; idea germination is the seeding stage of creative process and dreams are to be realised through aspirations and planning. These music entrepreneurs achieve their dreams with sustaining vital engagement maintaining full involvement to their work which involves attention, energy, meaningful engagement and enjoyment.

\section{Professional Collegial Affiliation}

Hill (1987) proposed four dimensions of affiliation motivation in support of maintaining closeness in interpersonal interaction for (1) social comparison; (2) emotional support; (3) positive stimulation; and (4) attention. Private music teachers generally teaching at home and working in isolation can be exhausting. To teach in an environment with co-operative and friendly relationship among colleagues can be potentially contribute to positive attitude and effective teaching. Professional 
collegial affiliation refers to working in environment with collegial collaboration and partnership; companionship and interaction among colleagues with shared vision and responsibility. This affiliation creates a community and network for music teachers to share expertise, knowledge and experiences.

ME 1 believed that working together and being with co-workers or colleagues who are committed to a common purpose can enhance the professional development especially with shared goals and values in music education. Collegiality between music colleagues is important in ensuring quality and maintaining excellence in the standards of music professionalism.

Music teachers working together in a collegial affiliated environment provide and motivation in sustaining the professional in-depth expertise. Collegial relationships provide space and scope to develop professional self-regulation in developing the maturity in their profession; in musical skills, knowledge and experience in music performance and teaching. The self-regulation process enables music teachers to monitor, evaluate, provide feedback and emotional self-control oneself and also direct each other to work towards achieving goals; help and support each other to increase own professional capacity leading to a successful music teaching career.

ME 2 shared her views on the collegial affiliation in music entrepreneurship where the music teachers make progress in their professional development, increase job opportunities, provide sense of team and cultivate team work. The affiliation motivation or the desire for warm relations with others (Hill, 2009, p. 410) is the need to maintain warm and close relationships with others (McClelland, 2010); and the need to connect, associate and interact with other people in warm and congenial ways (Hill, 2009, p. 410). Music teaching-learning require warm interpersonal relationships between teachers-students-parents and collegial interactions. Music teaching requires much communication and close and warm relationships with students and their parents. Working and teaching in isolation at home can be stressful and causing burn out.

The music entrepreneurs stated that they enjoy working with various types of people and gaining emotional satisfaction. ME 2 said that:

I love working with other colleagues and young people than working alone, it is not exciting.

They also indicated their high priority on the relationships and friendships with others. Warmth and friendliness are considered as the important personal characteristics of a music teacher and entrepreneur. In order to establish and to maintain affiliation, they share emotionally about friendship, ME 1 said,

I enjoy sharing ideas and experiences with friends and colleagues.

ME 3 established a choir 25 years ago and expressed fondly that its great enjoyment working with young people. She said, 
We are like a big family. The diverse activities in the choir enable the students to share varied musical experiences.....these varieties enable the members to develop creativity, positive attitudes and broaden musical thinking.

She positively thinks that the experiences of collaborating with each other open opportunities for musical and social possibilities where students learn to discover and unleash their own potentials through learning to work with each other.

ME 2 indicated that working private as a music teacher can be very lonely professionally and lacking emotional support in some stressful situation. However, in the entrepreneurial establishment and environment, there are more "colleagues" where the collegial "closeness and communication" enable each individual to share and acquire emotional support and positive affect. She said, "It is fun and enjoyable to work together with friends instead of working and teaching alone at home" and draws entrepreneurial inspiration from other, "I find inspiration for creative ideas when working together with others". She views collegiality as a valuable relationship to be treasured. It is a celebration of their mutual passion of music learning and teaching, their creativity and a powerful source for professional growth.

Attention, praise and respect from others have the least concern from the participants. ME 1 as an experienced music educator and music entrepreneur reflects that:

There is always praise and criticism ... I embrace criticism; it is a valuable tool for sharpening each other ... and (she paused) ... be humbled by compliments and praise.

These women music entrepreneurs shared their views on constructive elements in social comparison, emotional support, positive stimulation and attention through collegial interaction. As stated by Hill (1987, 2009), social comparison is the desire to reduce ambiguity, uncertainty and confusion through seeking through seeking information about the opinions, beliefs, attitudes and expectation and other socially relevant attributes. Hill (1987) also referred emotional support as reducing negative affects through social contact (p. 1008); to obtain relief from stress and fear through receiving sympathy, compassion, and nurturance. Further, Hill's (1987) also transpired the notion of positive stimulation as an important social incentive that receives gratification from pleasant relationships which gives a sense of closeness to others (p. 1009) which involves a desire for affection, love, intimacy and sense of belonging (Hill, 2009, p. 419). Lee (2005) in the study of women entrepreneurs also noted that the desire to engage with social contact is to experience the positive affect of stimulation related to interpersonal closeness and communication (p. 184).

\section{Family and Home Environment}

Through the interviews, the participants shared that musical orientated environment has enhanced their childhood with music-rich experience. ME 3 remembered her childhood home environment as musical. She recalled that her parents' enjoyment in 
performing arts provides her a unique musical experience and opportunity of cultural encounter,

My parents enjoy performing arts especially music. We had lots of exposure to cultural activities during my childhood and youth.

ME 1 and 2 participated actively in church and school musical activities. They were provided much opportunity to play leading roles in church festive musical productions and musicians at school ceremonies. ME 2 shared her fond memories:

I am always acted as Mary in the Christmas musical play!

Both ME 1 and 2 both shared the some responsibilities serving at church and school, they remembered their early memories:

I am the pianist for the church, when I was just an advanced beginner at piano playing...... and to play the piano accompany the singing the national and school anthem during school ceremonies.

They indicated that the immersion in musical environment during childhood and youth provided them the musical enculturation which promotes aesthetic attitudes that inspire them to challenge themselves to approach music education from a more holistic perspective and prepare them into music entrepreneurship.

From the findings, it was indicated that the family influence on these music entrepreneurs was not the exposure to business idea but environmental surrounding with music, arts and cultural enculturation and to acquire aesthetic values that shape their future. These childhood music environment and experiences made important contribution to their entrepreneurial impulse. It was found in the previous studies that parental influence and early life experience has it relationships to leadership skills in the future (Avolio, Rotundo, \& Walumbwa, 2009; Drennan, Kennedy, \& Renfrow, 2005) as entrepreneurs.

\section{Mentor and Role Model}

The decision to become a music entrepreneur can be influenced by few factors. Often, there is an influential individual, a role model or a mentor. Role model refers to individuals who 'stimulate or inspire other individuals' (Bosma, Hessels, Schutjens, Van Praag, \& Verheul, 2012, p. 410) in career decision and goals achievement. Studies were conducted to investigate the influence of role model on potential entrepreneurs and indicated the positive impact on nascent entrepreneurs' intentions in business start-up (Van Auken, Fry, \& Stephens, 2006) and boost perceptions of entrepreneurial feasibility and desirability (Fellnhofer \& Puumalainen, 2017). Zozimo, Jack and Hamilton (2017) conducted a study on young entrepreneurs observing role models (parents, teachers, colleagues, other entrepreneurs). The findings yield significance results in entrepreneurial learning 
and gaining entrepreneurial experiences from the role models at different contexts. A recent study conducted by Wyrwichm, Sternberg and Stuetzer (2018) indicated a contradict view in which a failed role model can trigger negative attitude and entrepreneurial fear of failure.

In this study, the women music entrepreneurs attributed the positive and valuable influence of their mentors and role models. ME 1 credited the influence and guidance from her mentor as the sparks that stimulate her to engage on entrepreneurship. She acknowledges her mentor as:

$\mathrm{He}$ is the role model with multi-expertise ... with much innovative ideas and strategies in music education and music business.

ME 2 and 3 regard their spouse as mentors, as they encourage and inspire them to set own life goals and support their individual efforts to attain success. All of them also identified their music teachers as their role model whom they admire their achievement and dedication to their work and aspire to becoming like them. They remembered their role model, other than being a music teacher; they have their unique entrepreneurial qualities and personality. ME 1 described her role model as "creative and able to attract students" and enterprising with "innovative business strategies", while ME 2 praised her inspiring role model as "musical", "accomplished pianist" whom makes efforts to enhance and improve students' lives through music. ME 3 said she is thankful to the choir teacher whom has an impact on developing and nurturing on her future entrepreneurial endeavour in setting up a community choir to improve quality of life, and wellbeing of young people. In sum, role models have a profound influence on their entrepreneurial intention and activities.

The characteristics of the role model described by the participants are similar to Bosma et al (2012) accounts of the presence of a role model who provided important functions such as 'confidence', 'stimulate', 'motivate', 'practical advice' (p. 418) and 'inspire', 'support' (p. 418).

\section{Meaningful Experience}

The decision to start a business can be prompted by various reasons. In a longitudinal study, Schoon and Duckworth (2012) examined the lives of 6116 young people from birth to the age of 34 in their commitment to entrepreneurial career. The contributing concepts examined include family background (socioeconomic and parental role model); and personal attributes (academic ability, social skills and self-concepts). Their finding indicates that early life experience shapes the prospect career choice and predicts entrepreneurial decision. Colombatto and Melnik (2007) also suggest that early work experience has positive impact on entrepreneurship. Beni, Flectcher and Chroinın (2018) proposed some features of meaning experience including social interaction, fun, challenges, relevant learning and delight (p. 1).

From the interview, the data shown significant information on the 
participants' experience traveling abroad in their youth has great influence on their latter entrepreneurial intentions. They stated that traveling is a meaningful experience where they assimilate cultural awareness and benefits. ME 2 indicated that her travel grant from a prestige music conservatoire in her youth provided meaningful experience to learn and grow from cultural experience. She stated that the traveling experience has positive impact on her personal qualities, such as personal development, gaining new perspectives and self-confidence which are vital as an entrepreneur.

Similarly, ME 3 also shared her traveling experience, where she had performing opportunities in foreign countries and was aspired for her students to have similar experiences. She stated that traveling is not just for pleasure but a means of learning, to understand culture and creative activities in a wider perspective. Her choir group has performed several times abroad where the members gained educational benefits include independence; life skills include problem solving and communication. She acknowledged that meaningful traveling experience has rewards in developing entrepreneurial aspiration in her music career.

ME 1 enjoys traveling, she shared her experience fondly:

...seeing new places, making new friends provide new perspectives, new way of knowing, new way of thinking.

Hensel (2015) examined the impact of travelling experience among 3 music participants and identify 'travel is transformative' (p. 13) which changes one's perspectives in worldview, enhances cultural enrichment and understanding. Travelling also the benefits of educational value in developing life skills and generate new knowledge (p. 14).As Stone and Petrick (2013) suggested, traveling is educational and the best way to learn and interpret experiences; and broadening the mind (p. 1). ME 1 further reflected on the learning from traveling, stating that the value and merit of these experiences had enrich her music and teaching experience, and widen her entrepreneurial horizon. She further explained that the traveling experience has its continual contribution in her entrepreneurial development in generating creative ideas, innovative strategies, rethinking self-fulfilment, gaining new knowledge and new perspective of entrepreneurial values.

Other than travelling as meaningful experience, previous studies have indicated the relations between environmental factors and entrepreneurial intention (Orhan, 2005, p. 7). It was stated that the decision on choosing entrepreneurship possibly grounded in family environment or presence of inspiring role models (Orhan, 2005, p. 8) and prior meaningful experience. The music entrepreneurs in this study have indicated that their pull motivation into music entrepreneurship are characterised by family and environment, role models and meaningful experience.

\section{Closing Comments}

The purpose of this study was to explore the pull motivational and influencing factors of the entrepreneurial intention of the Malaysian women music 
entrepreneurs. From the analysis of the interview data, eight emergent themes clustered about the pull motivation and environment factors that influence the entrepreneurship intention. Themes related to pull motivation include: (1) selffulfilment; (2) passion; (3) challenge and risk taking; (4) opportunities seeking; and (5) professional collegial affiliation. Themes related to environment factors include: (1) family and home environment; (2) mentor and role model; and (3) meaningful experience.

Drawing from the findings, it is indicated that the participants have individual personality traits, characteristics capabilities and personal resources to achieve success in the music business. The motive force that initiates the drive to venture into music entrepreneurship is to fulfil their aspiration for self-growth; to challenge their potential in realising the creative achievement and to strive for excellence in the quality of their music profession. The participants also revealed that professional knowledge and experience were favourable conditions and vital stimulant for their competencies and self-confidence. The environmental factors were also effectively shaping their attitudes towards challenges and changes. As suggested by Van der Boon (2005), pull factors that attract women into enterprise include: (1) self-fulfilment; (2) self-determination; (3) sense of accomplishment; (4) control; (5) profit and rewards; (6) challenges; and (7) family security (p. 163). Similarly, Stefanovic, Prokic and Rankovic (2010) also indicated that personal attributes like determination for independence; innovative direction; risk-taking and desire to succeed are essential for successful entrepreneurship (p. 254). Fisher and Koch (2008) also described entrepreneurs as "optimistic, extroverted, energetic, self-confident, and visionary" (p. 1); competitive, risk taking and risk seeking (p. 3).

Gerald Klickstein shared a quote from Isaac Stern saying that "To be musician in the service of music is not a job; it is a way of life" in The Musician's Way (2009, p. 299). Indeed, as musicians, loving music is a way of life; as a music educator, passion in teaching is the way of life; as a music entrepreneur, innovation and creativity is the way of life. To the music teachers as entrepreneurs in this study, it is a "way of life", a gratifying process for self-fulfilment. Artistic vision and education vision is another way to expand their knowledge and skills; not just seeking for opportunities but to create opportunities. Their value and belief include high level of performance; seeking for musical excellence; equipped themselves with entrepreneurial tools and aspired to be the one that to inspire the others and also be inspired. The music entrepreneurs integrate these professional identities and qualities to attain achievement in their music entrepreneurship.

In sum, the participants in this study can be regard as 'pure entrepreneurs' (Orhan, 2005, p. 13) with innovative ideas and aspired to transfer into reality. These innovative ideas and strategies derived from their prior meaningful experience which fuel their enthusiasm and passion as the driving force for entrepreneurship. They were attracted to 'educational entrepreneurship' (Hess, 2007, p. 23) to immerse and engage in an innovative process to quality in music education.

The findings provide insights into the entrepreneurial motivation and influencing factors of female music teachers venturing into music entrepreneurship. The study delimitated to only the 3 female music teachers which is a relatively small 
sample size. In order to have a broader understanding, it is suggested to explore more perspectives from a larger sample. This study also focusses on music entrepreneurs who have been in the music business for 25 years. For the future studies, it is suggested to explore music entrepreneurs of different experiences, comparing nascent and novice music entrepreneurs with the experienced music entrepreneurs for a deeper understanding of entrepreneurial motivation and process.

\section{Funding}

This research (project number: BK030-2016) was based on a grant awarded by the University Malaya Research Fund Assistance (BKP).

\section{References}

Aftan, Y., \& Hanapi, M. (2018). The impact of entrepreneurial motivation on small business performance in Iraq. International Journal of Academic Research in Business and Social Sciences, 8(1), 409-419.

Arora, R. (2015). Perspectives of entrepreneurship and its impact on stakeholders' co-creation. In H. R. Kaufmann, \& S. R. Shams (Eds.), Entrepreneurial challenges in the 21 st Century: Creating stakeholder value co-creation ( $\mathrm{pp}$. 1-11). UK: Palgrave Macmillan.

Avolio, B. J., Rotundo, M., \& Walumbwa, F. O. (2009). Early life experiences as determinants of leadership role occupancy: The importance of parental influence and rule breaking behavior. The Leadership Quarterly, 20(3), 329-342.

Barba-Sánchez, V., \& Atienza-Sahuquillo, C. (2017). Entrepreneurial motivation and self-employment: Evidence from expectancy theory. International Entrepreneurship and Management Journal, 13(4), 1097-1115.

Barker, A. (2017). Music Entrepreneurship. In K. Peppler (Ed.), The SAGE encyclopedia of out-of-school learning (pp. 517-522). Thousand Oaks, California, CA: SAGE Publications, Inc.

Beni, S., Fletcher, T., \& Chroinın, D. N. (2018). Using features of meaningful experiences to guide primary physical education practice. European Physical Education Review, 1-17.

Bhansing, P. V., Hitters, E., \& Wijngaarden, Y. (2017). Passion inspires: Motivations of creative entrepreneurs in creative business centres in the Netherlands. The Journal of Entrepreneurship, 27(1), 1-24.

Bosma, N., Hessels, J., Schutjens, V., van Praag, M., \& Verheul, I. (2012). Entrepreneurship and role models. Journal of Economic Psychology, 33(2), 410-424.

Braun, V., \& Clarke, V. (2006). Using thematic analysis in psychology. Qualitative Research in Psychology, 3(2), 77-101.

Cardon, M. S., Zietsmab , C., Saparitoc , P., Matherned , B. P., \& Davise , C. 
(2005). A tale of passion: New insights into entrepreneurship from a parenthood metaphor. Journal of Business Venturing, 20(1), 23-45.

Cardon, M., Wincent, J., Singh, J., \& Drnovsek , M. (2009). The nature and experience of entrepreneurial passion. The Academy of Management Review, 34(3), 511-532.

Chamorro-Premuzic, T., Rinaldi , C., Akhtara , R., \& Ahmetoglu, G. (2014). Understanding the motivations of female entrepreneurs. Journal of Entrepreneurship \& Organization Management, 3(1), 1-6.

Colombatto, E., \& Melnik, A. (2007). Early work experience and the transition into entrepreneurship. Journal of Entrepreneurial Finance and Business Ventures, 12(1), 9-26.

Dalborg, C., \& Wincent, J. (2015). The idea is not enough: The role of self-efficacy in mediating the relationship between pull entrepreneurship and founder passion. International Small Business Journal, 33(8), 974-984.

Denzin, N. K. (1989). The research act: A theoretical introduction to sociological methods (3rd ed.). Englewood Cliffs, NJ: Prentice Hall.

Drennan, J., Kennedy, J., \& Renfrow , P. (2005). Impact of childhood experiences on the development of entrepreneurial intentions. The International Journal of Entrepreneurship and Innovation, 6(4), 231 - 238.

Drucker, P. F. (1985). Innovation and entrepreneurship: Practice and principles. New York: Harper \& Row.

Elliott, D. J. (1995). Music matters: A new philosophy of music education. New York, NY: Oxford University Press.: Oxford University Press.

Fellnhofer, K., \& Puumalainen, K. (2017). Can role models boost entrepreneurial attitudes? International Journal of Entrepreneurship and Innovation Management, 21(3), 274-290.

Fisher, J. L., \& Koch, J. V. (2008). Born, not made: The entrepreneurial personality. London: Praeger .

Fraenkel, J. R., Wallen, N. E., \& Hyun, H. H. (2012). How to design and evaluate research in education (8th ed.). New York, NY: McGraw-Hill.

Gewirth, A. (1998). Self-Fulfillment. Princeton, NJ: Princeton University Press.

Helsel, B. R. (2015). To tour or not to tour: A case study in music education ensemble travel. Excellence in Performing Arts Research, 2, 1-22.

Hess , F. (2007). The case for educational entrepreneurship: Hard truths about risk, reform, and reinvention. Phi Delta Kappan, 89(1), 21-30.

Hill, C. A. (1987). Affiliation motivation: people who need people ... but in different ways. Journal of Personality and Social Psychology, 52(5), 1008-1018.

Hill, C. A. (2009). Affiliation motivation. In M. R. Leary , \& R. H. Hoyle (Eds.), Handbook of individual differences in social behavior (pp. 410-425). New York, NY: Guilford Press.

Klickstein, G. (2009). The musician's way: A guide to practice, performance, and, wellness. New York, NY: Oxford University Press.

Kokun, O. M. (2015). Professional self-fulfilment of skilled people of different professional groups and specialities. Social Welfare. Interdisciplinary Approach, 5(2), 19-32. 
Laaksonen, L., Ainamo, A., \& Karjalainen, T. M. (2011). Entrepreneurial passion: An explorative case study of four metal music ventures. Journal of Research in Marketing and Entrepreneurship, 13(1), 18-36.

Lee, J. (2005). Women entrepreneurs in Singapore. In S. L. Fielden , \& M. J. Davidson (Eds.), International handbook of women and small business (pp. 178-192). Cheltenham, UK: Edward Elgar.

Maslow, A. H. (1987). Motivation and personality (3rd ed.). Delhi, India: Pearson Education.

Mas-Tur, A., Soriano , D. R., \& Roig-Tierno, N. (2015). Motivational factors of female entrepreneurs. In V. Ramadani , S. Gërguri-Rashiti , \& A. Fayolle, Female entrepreneurship in transition economies (pp. 31-44). London: Palgrave Macmillan.

McClelland, D. C. (2010). The achieving society. Martino Fine Books.

Mirchandani, K. (2005). Women's entrepreneurship: Exploring new avenues. In S. L. Fielden, \& M. J. Davidson (Eds.), International handbook of women and small business entrepreneurship (pp. 253-263). Cheltenham, UK: Edward Elgar .

Morris, A. (2015). A practical introduction to in-depth interviewing. London: Sage.

Nassif, V., Andreassi, T., Tonelli, M., \& Fleury, M. T. (2012). Women entrepreneus: Discussion about their competencies. African Journal of Business Management, 6(26), 7694-7704.

Oltmann, S. (2016). Qualitative interviews: A methodological discussion of the interviewer and respondent contexts. Forum: Qualitative Social Research, $17(2)$.

Orhan, M. (2005). Why women enter into small business ownership. In S. L. Fielden, \& M. J. Davidson (Eds.), International handbook of women and small business entrepreneurship (pp. 3-16). Cheltenham, UK: Edward Elgar.

Pandey, V. (2013). Factors influencing entrepreneurial motivation of women entrepreneurs. BVIMSR's Journal of Management Research, 5(2), 101-108.

Przepiorka, A. (2016). What makes successful entrepreneurs different in temporal and goal-commitment dimensions? Time \& Society, 25(1), 40-60.

Schoon, I., \& Duckworth, K. (2012). Who becomes an entrepreneur? Early life experiences as predictors of entrepreneurship. Developmental Psychology, 48(6), 1719-1726.

Seidman, I. (2013). Interviewing as qualitative research: A guide for researchers in education and the social sciences (4th ed.). New York: Teachers' College Press.

Shane, S., Locke, E. A., \& Collins, C. J. (2003). Entrepreneurial motivation. Human Resource Management Review, 13(2), 257-279.

Short, J. C., Ketchen Jr, D. J., Shook, C. L., \& Ireland, R. D. (2010). The concept of "opportunity" in entrepreneurship research: Past accomplishments and future challenges. Journal of Management, 36(1), 40-65.

Smith, J. (2014). Entrepreneurial music education. In M. Kaschub, \& J. Smith (Eds.), Promising practices in 21st century music teacher education (pp. 61- 
78). New York, NY: Oxford University Press.

Spinelli Jr, S., \& Adams, R. (2012). New venture creation: Entrepreneurship for the 21 st century (9th ed.). New York, NY: The McGraw-Hill Companies.

Stefanovic, I., Prokic, S., \& Ranko, L. (2010). Motivational and success factors of entrepreneurs: the evidence from a developing country. Zbornik Radova Ekonomskog Fakultet au Rijeci, 28(2), 251-269.

Stone , M. J., \& Petrick, J. F. (2013). The educational benefits of travel experiences: A literature review. Journal of Travel Research, 52(6), 731 - 744.

Suárez-Ortega, M., \& Gálvez-García, R. (2017). Motivations and decisive factors in women's entrepreneurship. A gender perspective in education and professional guidance. Procedia Social and Behavioral Sciences, 237, 1265 $-1271$.

Tlaiss, H. A. (2015). Entrepreneurial motivations of women: Evidence from the United Arab Emirates. International Small Business Journal, 33(5), 562581.

Van Auken, H., Fry , F., \& Stephens, P. (2006). The influence of role models on entrepreneurial intentions. Journal of Developmental Entrepreneurship, 11(2), 157-167.

Van der Boon, M. (2005). Women into enterprise-a European and international perspective. In S. L. Fielden, \& M. L. Davidson (Eds.), International handbook of women and small business entrepreneurship (pp. 161-177). Cheltenham: Edward Elgar.

Wallevik, K. (2015). The future of entrepreneurship: Concept and context. In H. Kaufmann, \& S. R. Shams (Eds.), Entrepreneurial challenges in the 21st century: Creating stakeholder value co-creation (pp. 12-23). UK: Palgrave Macmillan.

Wyrwich, M., Sternberg, R., \& Stuetzer, M. (2018). Failing role models and the formation of fear of entrepreneurial failure:A study of regional peer effects in German regions. Journal of Economic Geography, 1-21.

Zozimo, R., Jack , S., \& Hamilton, S. (2017). Entrepreneurial learning from observing role models. Entrepreneurship \& Regional Development, 29(910), 889-911.

\section{Biography}

Cheong Ku Wing is a senior lecturer at Cultural Centre, University of Malaya with a special interest in music education and music pedagogy. Her other research areas include musical thinking skills and musical creativity. 